\title{
Perilaku Perundungan Siber pada Remaja: Ditinjau dari Anger Management dan Pola Asuh Permisif
}

\author{
Moh Aminullah \\ Rani Yusriany \\ Marina Yollanda \\ Srimulyani Imran
}

\author{
Program Studi Magister Psikologi Profesi \\ Program Pascasarjana Universitas Ahmad Dahlan, Yogyakarta
}

\begin{abstract}
Cyberbullying has been developed in recent years. It has negative impacts for its victims such as low self esteem, anxiety, and depression. This study aims to examine the relationship between anger management and permissive parenting patterns with cyberbullying behavior in adolescents. The population in this study are adolescents aged 15-18 years who domiciled in Yogyakarta. The number of samples of this study were 122 adolescents. The research method used is quantitative method with scale as data collection tool. Scale used in this research is anger management scale, permissive parenting scale scale, cyberbullying behavior scale. Data analysis used is multiple regression analysis technique. The results of this study show the coefficient value $\mathrm{R}$ $=0.688$ with $p=0,000(p<0.01)$ which means there is a very significant relationship between anger management and permissive parenting patterns with cyberbullying behavior in adolescents and effective contribution of $47.3 \%$. Effective contribution of anger management variable is $38.5 \%$ and permissive parenting pattern is $8.8 \%$ to cyberbullying behavior
\end{abstract}

Keywords: anger management, cyberbullying behavior, permissive parenting

\begin{abstract}
Abstrak. Kasus perundungan siber pada remaja mulai semakin marak pada beberapa tahun terakhir. Perundungan siber berdampak negatif bagi korbannya dan berisiko menimbulkan harga diri rendah, kecemasan, hingga depresi. Penelitian ini bertujuan untuk menguji hubungan antara anger management dan pola asuh permisif dengan perilaku perundungan siber pada remaja. Populasi pada penelitian ini adalah remaja berusia 15-18 tahun yang berdomisli di Yogyakarta. Jumlah sampel penelitian ini sebanyak 122 remaja. Metode penelitian yang digunakan adalah metode kuantitatif dengan skala sebagai alat pengumpulan data. Skala yang digunakan dalam penelitian ini adalah skala anger management, skala pola asuh permisif, skala perilaku perundungan siber. Analisis data yang digunakan adalah teknik analisis regresi berganda. Hasil penelitian ini menunjukkan nilai koefisien $\mathrm{R}=0,688$ dengan $\mathrm{p}=0,000(\mathrm{p}<0,01)$ yang berarti hipotetsis ini diterima yaitu terdapat hubungan yang sangat signifikan antara anger management dan pola asuh permisif dengan perilaku perundungan siber pada remaja dan sumbangan efektifnya sebesar $47,3 \%$. Sumbangan efektif variabel anger management sebesar 38,5\% dan pola asuh permisif sebesar $8,8 \%$ terhadap perilaku perundungan siber.
\end{abstract}

Kata Kunci: anger management, perilaku perundungan siber, pola asuh permisif

Korespondensi : Moh Aminullah. Email: aminullahmoh@gmail.com 
Perkembangan teknologi dan informasi yang semakin pesat, menuntut individu untuk mengikuti perkembangan yang ada, sehingga individu dapat tetap eksis dalam lingkungannya. Hal ini dilihat dari jumlah pengunaan internet yang semakin meningkat, mulai dari anak-anak sampai lansia. Di Indonesia, yang menggunakan internet sebanyak 132,7 juta orang dari total penduduk 256,2 juta. Pengguna internet sebanyak 75,5\% berusia 10 sampai 24 tahun, dengan 69,8\% adalah pelajar. Adapun konten yang diakses seperti media sosial sebanyak 97,4\%. Selain itu, sebanyak $69,9 \%$ orang mengakses internet dimana saja (APJII, 2016). Internet memudahkan individu dalam segala aspek kehidupan seperti memperoleh informasi terbaru dari berbagai penjuru dunia dengan cepat, menjalin silaturahmi, sebagai sarana mengekspresikan diri, tempat berbagi ilmu, dan sebagainya. Internet juga memiliki dampak negatif terhadap individu seperti mudahnya mengakses pornografi, sebagai sarana penipuan, dan membuat Individu cenderung lebih individualis. Selain itu, dampak lain dari penggunaan internet yaitu membuat individu melakukan perundungan siber (Rahayu, 2012).

Perundungan siber adalah tindakan mengirim atau mengunggah teks atau gambar berbahaya atau kejam menggunakan internet atau perangkat komunikasi digital lainnya. Perundungan siber dapat diposting di situs web pribadi, dan blog. Pesan teks perundungan siber dapat disebarkan melalui e-mail, online group, chatting, instant messaging dan pesan teks atau pesan gambar digital melalui perangkat telepon (Wilard, 2007). Bentukbentuk perundungan siber menurut Wilard (2007) yaitu, Flaming (terbakar) adalah mengirimkan pesan teks yang isinya merupakan kata-kata yang penuh amarah dan frontal. Istilah flame inipun merujuk pada katakata di pesan yang berapi-api. Harassment (gangguan) yaitu pesan-pesan yang berisi gangguan pada email, sms, maupun pesan teks di jejaring sosial yang dilakukan secara terus menerus. Cyberstalking yaitu mengganggu dan mencemarkan nama baik seseorang secara intens sehingga membuat ketakutan besar pada orang tersebut. Denigration (pencemaran nama baik) yaitu proses mengumbar keburukan seseorang di internet dengan maksud merusak reputasi dan nama baik orang tersebut. Impersonation (peniruan) yaitu berpura-pura menjadi orang lain dan mengirimkan pesan-pesan atau status yang tidak baik. Outing yaitu menyebarkan rahasia orang lain, atau foto-foto pribadi orang lain . Trickery (tipu daya) yaitu membujuk seseorang dengan tipu daya agar mendapatkan rahasia atau foto pribadi orang tersebut. Terakhir, Exclusion (pengeluaran) yaitu secara sengaja dan kejam mengeluarkan seseorang dari group online.

Perundungan siber banyak terjadi dikalangan remaja. Hal ini didukung oleh penelitian Rahayu (2012) yang di lakukan di kota Yogyakarta, Semarang, dan Magelang, yang 
menunjukkan bahwa $60 \%$ remaja belum memahami tentang perundungan siber, serta potensi dampak yang dapat ditimbulkannya, mereka hanya pernah mendengar dan mengetahui, bahkan menganggap bahwa perundungan siber wajar jika dilakukan oleh remeja. Remaja yang sudah mengalami perundungan siber cukup besar yaitu (28\%) dari 363 siswa, selain itu, 32\% mengatakan pernah melakukan perundungan siber, dengan alasan iseng (49\%). Remaja yang sering melakukan perundungan siber memilki rasa empati yang kurang atau tidak dapat merasakan hal burukyang dirasakan orang lain. Pelaku perundungan siber juga dapat dikenai hukum pidana yang berkaitan dengan undangundang Nomor 11 Tahun 2008 tentang Informasi dan Transaksi Elektronik. Dalam Undang-Undang ini terdapat pasal-pasal yang sesuai untuk menjerat para pelaku perundungan siber yaitu pasal 27 ayat 1, 3 dan 4 , pasal 28 ayat 1 dan 2 , serta pasal 29. Ancaman bagi pelaku tindak pidana sesuai pasal-pasal tersebut yaitu dikenakan hukuman 6-12 tahun penjara dan denda satu-dua miliar rupiah.

Dampak dari perundungan siber tidak hanya dirasakan oleh pelaku, tetapi juga oleh korban yaitu membuat korban menarik diri dari lingkungan sosial diikarenakan merasa malu akan dirinya yang mendapat perlakuan tidak menyenangkan secara online. Korban memandang dirinya tidak berharga, merasa tidak percaya diri ketika berada di lingkungan sosial, dan merasa hidupnya tidak berguna
(Stopbullying.gov). Jika korban mendapat perlakuan perundungan siber secara terusmenerus akan membuat korban menyakiti dirinya sendiri dan dampak lebih lanjutnya yaitu dapat mengakibatkan bunuh diri.

Salah satu faktor yang mempengaruhi perundungan siber pada remaja adalah peran interaksi orangtua dengan anak. Peranan orangtua dalam mengawasi aktivitas anak dalam berinteraksi di internet merupakan faktor yang cukup berpengaruh pada kecenderungan anak untuk terlibat dalam aksi perundungan siber (Pratiwi, 2011). Kurangnya pengawasan dan perhatian orangtua kepada anak menunjukkan bahwa pola asuh yang di gunakan orang tua adalah pola asuh permisif. Orang tua dengan pola asuh permisif tidak memiliki konsekuensi, peraturan dan hukuman bagi anak atas perbuatannya, serta pola komunikasi yang terjadi hanya satu arah saja yaitu dari anak, karena orangtua hanya mengikuti saja. Pola asuh permisif menurut Hurlock (2007), terdiri dari beberapa aspek yaitu, Pertama, kurangnya kontrol, termasuk tidak adanya pengarahan perilaku anak sesuai dengan norma masyarakat, tidak menaruh perhatian dengan siapa saja anak bergaul. Kedua, pengabaian keputusan, yaitu membiarkan anak untuk memutuskan segala sesuatu sendiri tanpa adanya pertimbangan dengan orangtua. Kegita, orangtua masa bodoh, yaitu ketidakpedulian orangtua terhadap anak, tidak adanya hukuman saat anak sedang melakukan tindakan yang melanggar norma, 
dan Keempat, pendidikan bersifat bebas, Hal ini mengenai kebebasan anak untuk memilih sekolah sesuai dengan keinginan anak, tidak adanya nasihat disaat anak berbuat kesalahan, kurang memperhatikan pendidikan moral dan agama.

Selain pola asuh permisif sebagai faktor pendorong terjadinya perilaku perundungan siber pada remaja, faktor internal pada diri remaja juga menjadi pendorong terjadinya perilaku perundungan siber yaitu strain. Strain merupakan suatu kondisi ketegangan psikis yang ditimbulkan dari hubungan negatif dengan orang lain yang menghasilkan afek negatif (terutama rasa marah dan frustasi) yang mengarah pada kenakalan (Pratiwi, 2011). Tice (Goleman, 2007) menyebutkan bahwa marah merupakan emosi negatif yang paling sulit dikendalikan. Emosi marah yang tidak dapat dikendalikan dengan baik dapat menimbulkan berbagai dampak negatif khususnya pada remaja, termasuk didalamnya terlibat tindakan kriminal di dunia maya (perundungan siber). Marah adalah perasaan yang perlu untuk diungkapan tanpa harus ada kebencian atau agresi, dengan cara individu memanajemen rasa marahnya (anger management).

Menurut Goleman (2007) pengelolaan emosi marah (anger management) merujuk pada cara seseorang mengatur perasaan dan pikiran-pikiran khasnya, suatu keadaan biologis dan psikologis serta serangkaian kecenderungan untuk bertindak. Aspek-aspek mengelola emosi marah menurut Goleman
(2007) yaitu, Pertama, mengenali emosi marah, yang ditunjukkan dengan mengenali perasaan marah sewaktu emosi marah muncul dalam diri sehingga individu tidak dikuasai oleh amarah. Kemampuan ini dapat dilakukan dengan mengenali atau mengetahui tanda-tanda awal yang menyertai kemarahan, sehingga mampu menghadapi perasaan mereka sendiri dengan baik. Kedua, mengendalikan emosi marah. Seseorang yang dapat mengendalikan emosi marah tidak membiarkan dikuasai oleh emosi marah. Kemarahan yang tidak terkendali dapat menimbulkan perilaku agresif baik verbal maupun non verbal. Mengendalikan amarah yaitu dengan mengatur emosinya dan menjaga keseimbangan emosi, sehingga emosi marah tidak berlebihan dan pada intensitas yang tinggi. Ketiga, meredakan emosi marah yaitu, kemampuan untuk menenangkan diri sendiri setelah individu marah. Salah satu srategi yang dilakukan individu secara umum untuk meredakan marah adalah pergi menyendiri, jalan-jalan, melakukan metode-metode relaksasi seperti menarik nafas dalam-dalam, dan berbagai kegiatan lainnya. Keempat, mengungkapkan emosi marah secara asertif. Orang yang asertif dapat mengungkapkan perasaan marahnya secara jujur dan tepat tanpa melukai perasaan orang lain.

Berdasarkan penjelasan di atas dapat dsimpulkan bahwa ada hubungan positif antara pola asuh permisif dengan perilaku perundungan siber pada remaja. Semakin tinggi pola asuh permisif semakin tinggi pula 
perilaku perundungan siber pada remaja. Sebaliknya, semakin rendah pola asuh permisif maka semakin rendah pula perilaku perundungan siber pada remaja. Selain itu, terdapat hubungan negatif antara anger management dengan perilaku perundungan siber pada remaja. Semakin tinggi anger management maka semakin rendah perilaku perundungan siber pada remaja. Sebaliknya, semakin rendah anger management maka semakin tinggi pula perilaku perundungan siber pada remaja.

\section{Metode}

\section{Desain penelitian}

Penelitian ini menggunakan metode kuantitatif, dengan merumuskan hipotesis dan dilakukan pengujian statistik untuk menerima atau menolak hipotesis yaitu hubungan anger management dan pola asuh permisif dengan perilaku perundungan siber. Variabel penelitian ini meliputi dua variabel bebas yaitu anger management (X1) dan pola asuh permisif (X2), serta satu variabel tergantung yaitu perilaku perundungan $\operatorname{siber}(\mathrm{Y})$.

\section{Populasi dan sampel}

Populasi pada penelitian ini merupakan remaja berusia 15-18 tahun yang berdomisli di Yogyakarta. Jumlah sampel penelitian ini sebanyak 122 remaja.

\section{Metode pengumpulan data}

Teknik pengambilan sampel yang dilakukan dengan menggunakan Non Probability Sampling jenis Accidental Sampling, yaitu yaitu pengambilan sampel secara aksidental (accidental) dengan mengambil responden yang kebetulan ada atau tersedia di suatu tempat sesuai dengan konteks penelitian (Notoatmodjo, 2010). Instrumen atau alat yang digunakan pengumpulan data adalah Skala Perundungan Siber oleh Wilard (2007), Skala Anger Management mengacu pada teori yang dikemukakan oleh Goleman (2007). Sedangkan Skala Pola Asuh Permisif mengacu pada teori Hurlock (2007).

\section{Metode analisis data}

Teknik analisis yang digunakan untuk mengukur anger management dan pola asuh permisif dengan perilaku perundungan siber adalah regresi berganda dengan menggunakan SPSS versi 20. Teknik analisis regresi berganda yaitu prosedur yang digunakan untuk mengetahui ada tidaknya hubungan antara pola asuh permisif dan anger management dengan perilaku perundungan siber.

\section{Hasil}

\section{Uji asumsi}

Sebelum dilakukan analisis regresi, terlebih dahulu perlu dilakukan uji asumsi terhadap data yang telah dikumpulkan. Tujuan dilakukan uji asumsi adalah agar keputusan yang diambil berdasarkan hasil analisis, valid dan reliabel. Uji asumsi yang digunakan adalah uji normalitas sebaran, uji linearitas, dan uji 
multikolinearitas. Ketiga uji asumsi tersebut digunakan dengan alasan bahwa model data penelitian adalah parametrik dengan mengunakan model analisis korelasi regresi.

Pengujian normalitas menggunakan teknik statistik one-sample KolmogorovSmirnov test. Hasil uji normalitas yang menunjukkan bahwa variabel perundungan siber memiliki $p=0,132(p>0,05)$. Variabel anger management memiliki $\mathrm{p}=0,503$ ( $\mathrm{p}>0,05)$. Variabel pola asuh permisif memiliki $\mathrm{p}$ $=0,374(\mathrm{p}>0,05)$. Berdasarkan hasil uji normalitas tersebut maka dapat disimpulkan bahwa masing-masing variabel penelitian memiliki sebaran data yang terdistribusi normal.

Uji linieritas bertujuan untuk melihat apakah dari sebaran titik-titik yang merupakan nilai dari variabel-variabel penelitian dapat ditarik garis lurus yang menunjukkan sebuah hubungan linier antara variabel-variabel tersebut atau dapat dikatakan untuk mengetahui hubungan antara variabel bebas dan varibel terikat linier atau tidak. Kriteria pengujian linieritas adalah jika nilai signifikansi pada linierity kurang dari $0,05(<0,05)$ dan deviation from linierity lebih besar dari 0,05 (> $0,05)$ maka hubungan antara variabel bebas dengan variabel terikat linier. Signifikansi Linearity $(\mathrm{p})$ variable anger management dengan perundungan siber sebesar 0,000 (< 0,05 ) yang artinya hubungan kedua variabel linear, sedangkan pada variabel pola asuh permisif dengan perundungan siber sebesar $0,000(<0,05)$, artinya hubungan kedua variabel linier.

Uji multikolinieritas bertujuan untuk membuktikan atau menguji ada tidaknya hubungan yang linear diantara variabel independent. Kriteria yang digunakan adalah nilai VIF kurang dari $10(<10)$ dan nilai tolerance lebih dari $0,1(>0,1)$ maka tidak terdapat hubungan multikolinearitas. Hasil uji multikolinearitas pada variabel anger management dan pola asuh permisif diketahui nilai VIF seebesar 1,319 dan nilai toleransi lebih dari 0,1 yaitu 0,758 yang mendekati 1 sehingga dapat dikatakan tidak terjadi multikolinearitas.

\section{Uji hipotesis}

Penelitian ini menggunakan teknik analisis regresi berganda untuk menguji hipotesis penelitian dengan bantuan software SPSS 20. Ada 3 hipotesis dari penelitian ini. Hasil Uji Hipotesis 1 (H1), pengujian hipotesis ini untuk mengetahui berapa persen atau seberapa besar varians variabel tergantung (DV) yang dijelaskan oleh variabel bebas (IV). Hasil perhitungan untuk hipotesis 1 dapat dilihat pada tabel 1 berikut:

Tabel 1. Korelasi Anger Management dan Pola Asuh Permisif

\begin{tabular}{cccc}
\multicolumn{4}{l}{ dengan Perilaku Perundungan Siber } \\
\hline Model & $\mathrm{r}$ & $\mathrm{r}^{2}$ & Sig. F Change \\
\hline 1 & .688 & .473 & .000 \\
\hline
\end{tabular}


Tabel 2. Koefisien Regresi Anger Management dengan Perundungan Siber

\begin{tabular}{lcc}
\hline Model & Unstandardized Coeficients & $\mathrm{p}$ \\
& $\mathrm{B}$ & \\
\hline (Constant) & 41,796 &, 000 \\
Anger Management &,- 485 &, 000 \\
Pola Asuh Permisif &, 186 &, 005 \\
\hline
\end{tabular}

Berdasarkan hasil uji hipotesis 1 pada Tabel 1 diketahui bahwa nilai koefisien $r=0,688$ dengan $\mathrm{p}=0,000 \quad(\mathrm{p}<0,01)$ yang berarti terdapat hubungan yang sangat signifikan antara anger management dan pola asuh permisif dengan perilaku perundungan siber pada remaja dan sumbangan efektifnya sebesar $r^{2}=0,473(47,3 \%)$.

Hipotesis 2 yaitu hubungan antara anger management dengan perilaku perundungan siber dapat dilihat pada tabel 2.

Pada tabel 2 menunjukkan nilai koefisien $\mathrm{B}=-, 485$ dengan taraf signifikansi $\mathrm{p}=0,000(\mathrm{p}$ $<0,01$ ) yang artinya ada hubungan yang sangat signifikan antara anger management dengan perilaku perundungan siber.

Hipotesis 3 yaitu hubungan antara pola asuh permisif dengan perilaku perundungan siber dapat dilihat pada tabel 2 .

Pada tabel 2 menjelaskan bahwa hipotesis hubungan antara pola asuh permisif dengan perilaku perundungan siber diterima yang menunjukkan nilai koefisien $B=0,186$ dengan taraf signifikansi $p=0,005(p<0,01)$ yang artinya ada hubungan yang sangat signifikan antara pola asuh permisif dengan perilaku perundungan siber pada remaja.

Berdasarkan paparan di atas, maka secara bersama-sama anger management dan pola asuh permisif mampu menjadi prediktor atas perilaku perundungan siber. Selain itu, jika ditelaah untuk masing-masing variabel bebas, maka anger management dan pola asuh permisif juga memiliki hubungan yang signifikan. Dengan demikian, hipotesis dalam penelitian ini diterima.

\section{Pembahasan}

Hasil penelitian menunjukan terdapat hubungan yang sangat signifikan antara anger management dan pola asuh permisif dengan perilaku perundungan siber dengan nilai $p=0,000(p<0,01)$. Remaja yang melakukan perundungan siber dapat dikatakan dipengaruhi oleh anger management dan pola asuh permisif orang tuanya. Dari hasil analisis regresi berganda diperoleh $\mathrm{R}^{2}=0,473$, artinya bahwa sumbangan efektif dari variabel anger management dan pola asuh permisif terhadap perilaku perundungan siber remaja sebesar $47,3 \%$, dan $52,7 \%$ dipengaruhi oleh variabel yang lainnya. Sumbangan efektif variabel anger management memberikan kontribusi sebesar $38,5 \%$ dan pola asuh permisif memberikan kontribusi sebesar 8,8\%, hal ini menunjukan bahwa anger management memberikan 
kontribusi yang lebih tinggi dari pada pola asuh permisif. Dengan demikian dapat dikatakan bahwa remaja yang melakukan perundungan siber sebesar 38,5\% dipengaruhi oleh anger management dan 8,8\% dipengaruhi oleh pola asuh permisif.

Hasil penelitian ini sejalan dengan hasil penelitian yang dilakukan oleh Pratiwi, (2011) menunjukan bahwa peranan orang tua dalam mengawasi aktivitas anak dalam berinteraksi di internet merupakan faktor yang cukup berpengaruh pada kecenderungan anak untuk terlibat dalam aksi perundungan siber. Orang tua yang tidak ada pengawasan terhadap aktivitas anak di media sosial memiliki kecenderungan perilaku perundungan siber. Di media sosial Kebanyakan remaja mengaku bahwa mereka membuat facebook secara sembunyi-sembunyi, dan tidak mau menambahkan orang tuanya untuk menjadi temannya di facebook. Hal ini membuat orang tua tidak tahu jika anak mereka membully atau dibully orang di dunia sosial (Maya, 2015). Hurlock (2007) mendefinisikan pola asuh permisif sebagai pola asuh yang tidak memiliki konsekuensi, peraturan dan hukuman bagi anak atas perbuatannya serta pola komunikasi yang terjadi hanya satu arah saja yaitu dari anak karena orang tua hanya mengikuti saja. Orang tua dengan pola asuh permisif akan membentuk anak yang bertindak sekehendak hati, tidak mampu mengendalikan diri, selalu memaksakan kehendak, tidak mampu membedakan baik dan buruk serta membuat anak menjadi tidak matang dan mandiri (Surbakti, 2009).

Berdasarkan hasil uji hipotesis menunjukan terdapat hubungan positif yang sangat signifikan antara pola asuh permisif terhadap perundungan siber remaja dengan nilai $\beta=0,186$ dan $t_{\text {hitung }}$ sebesar 2,871 dengan $p$ $=0,005(p<0,01)$, dengan demikian dapat dikatakan bahwa semakin tinggi pola asuh permisif maka akan semakin tinggi pula perilaku perundungan siber remaja, sedangkan semakin rendah pola asuh permisif maka semakin rendah perilaku perundungan siber remaja. Adapun sumbangan efektif (SE) yang diberikan oleh variabel pola asuh permisif terhadap perundungan siber sebesar 8,8\%, sedangkan 91,2 \% dipengaruhi oleh variabel lain

Hasil penelitian ini juga sejalan dengan penelitian Priyatna (2010) yang menyatakan bahwa remaja merasakan banyak emosi negatif seperti marah, sakit, malu atau takut ketika mereka mengalami perundungan siber. Emosi negatif yang dirasakan remaja membuat dirinya membalaskan dendam dan menjadi pelaku perundungan siber (Priyatna, 2010). Tice dalam Goleman (2007) mendefinisikan anger management sebagai kemampuan untuk mengelola pikiran, perasaan, nafsu amarah, dengan cara yang tepat dan positif serta dapat diterima secara sosial, sehingga dapat mencegah sesuatu yang buruk atau merugikan diri sendiri dan orang lain. Namun remaja yang memiliki skills anger management yang baik 
dapat menurunkan prilaku maupun pikiran agresif secara total, termasuk perilaku perundungan siber (Valizadeh, Davaji, \& Nikamal, 2010).

Berdasarkan hasil analisis penelitian menunjukan bahwa terdapat peran negatif yang sangat signifikan antara anger management terhadap perundungan siber pada remaja dengan nilai $\beta=-0,485$ dan $t_{\text {hitung }}$ sebesar $-7,238$ dengan $p=0,000(p<0,01)$, dengan demikian dapat dikatakan bahwa semakin tinggi anger management maka akan semakin rendah perilaku perundungan siber remaja, sedangkan semakin rendah anger management maka semakin tinggi perilaku perundungan siber remaja. Adapun sumbangan efektif (SE) yang diberikan oleh variabel anger management terhadap perundungan siber sebesar $38,5 \%$, sedangkan $61,5 \%$ dipengaruhi oleh variabel lain.

Hasil lain dari uji kategorisasi diketahui bahwa mayoritas subjek dalam penelitian ini berada pada kategori sedang dari semua variabel. Sebanyak 81 subjek atau 66,39 \% berada di kategori sedang pada variabel perundungan siber. 19 subjek atau 15,57 \% berada di kategori tinggi pada variabel perundungan siber. 22 subjek atau 18,03 \% berada di kategori rendah pada variabel perundungan siber. Sebanyak 76 subjek atau 62,29\% berada di kategori sedang pada variabel anger management. 25 subjek atau $20,49 \%$ berada di kategori tinggi pada variabel anger management. 21 subjek atau 17,21 \% berada di kategori rendah pada variabel anger management. Sebanyak 70 subjek atau 57,37 \% berada di kategori sedang pada variabel pola asuh permisif. 26 subjek atau $21,31 \%$ berada di kategori tinggi pada variabel pola asuh permisif. 26 subjek atau 21,31 \% berada di kategori rendah pada variabel pola asuh permisif.

Keterbatasan penelitian ini adalah peneliti menggunakan teknik sampling accidental sehingga jumlah sampel mungkin tidak representatif karena hanya tergantung pada anggota sampel yang ada pada saat itu saja. Pada penelitian ini juga belum mencantumkan pertanyaan pada kuesioner tentang seberapa lama penggunaan gadget yang memiliki akses internet sebelum mengisi skala penelitian.

\section{Simpulan}

Berdasarkan hasil analisis data penelitian maka kesimpulan yang dapat diambil dalam penelitian ini antara lain yaitu ada hubungan yang sangat signifikan antara anger management dan pola asuh permisif dengan perilaku perundungan siber pada remaja yang memiliki sumbangan efektif sebesar 47,3\%. Ada hubungan negatif yang sangat signifikan antara anger management dengan perilaku perundungan siber pada remaja dengan sumbangan efektif sebesar $38,5 \%$. Artinya, semakin tinggi anger management maka semakin rendah perilaku 
perundungan siber pada remaja, sebaliknya semakin rendah anger management maka semakin tinggi perilaku perundungan siber pada remaja. Ada hubungan positif yang sangat signifikan antara pola asuh permisif dengan perilaku perundungan siber pada remaja dengan sumbangan efektif sebesar 8,8\%. Artinya, semakin tinggi pola asuh permisif maka semakin tinggi pula perilaku perundungan siber pada remaja, sebaliknya semakin rendah pola asuh permisif maka semakin rendah pula perilaku perundungan siber pada remaja.

Penelitian ini memiliki kelebihan terkait dengan pengukuran variabel bebas/variabel yang mempengaruhi yaitu pada penelitian ini mengukur perilaku perundungan siber ditinjau dari faktor internal (anger management) dan faktor eksternal (pola asuh permisif), sehingga hasil penelitian ini dapat memberikan informasi yang lengkap mengenai faktor yang mempengaruhi perilaku perundungan siber.

\section{Saran}

Peneliti selanjutnya disarankan dapat meneliti dan mengembangkan variabelvariabel lain yang dapat memperkaya hasil penelitian mengenai faktor-faktor lain yang dapat mempengaruhi perilaku perundungan siber yang tidak diungkap dalam penelitian ini. Bagi peneliti selanjutnya juga diharapkan mampu menggunakan teknik sampling yang bersifat random agar sampel dapat representatif dalam meneliti perilaku perundungan siber. Peneliti selanjutnya juga disarankan untuk mencantumkan pertanyaan pada kuesioner sebelum dilaksanakan penelitian mengenai seberapa lama penggunaan gadget yang memiliki akses internet agar dapat meminimalisir kesalahan dalam pemilihan subjek yang nantinya dapat memberikan pengaruh pada hasil data.

Berdasarkan hasil penelitian diketahui bahwa remaja dengan anger management yang tinggi mempunyai hubungan erat dengan rendahnya perilaku perundungan siber. Oleh karena itu disarankan kepada remaja untuk lebih meningkatkan anger management. Hal yang dapat dilakukan remaja untuk meningkatkan anger management yaitu remaja disarankan untuk mengenali emosi marah, mampu meredakan emosi marah dengan cara yang positif, dan mampu mengungkapkan rasa marah secara langsung kepada pihak yang bersangkutan dengan cara yang dapat diterima yaitu menggunakan tutur bahasa yang tidak menyakiti pihak tertentu. Hal ini akan memicu timbulnya anger management yang baik pada remaja sehingga akan menurunkan perilaku perundungan siber pada remaja.

Berdasarkan hasil penelitian diketahui bahwa remaja dengan pola asuh permisif yang rendah mempunyai hubungan erat dengan rendahnya perilaku perundungan siber. Oleh karena itu disarankan kepada orang tua yang memiliki anak untuk memberikan pola asuh dengan memberikan kebebasan kepada anak untuk berekspresi dalam hal yang positif, namun tetap memberi pengawasan pada 
aktivitas anak. Orang tua juga disarankan untuk saling bertukar pikiran dengan anak dalam menentukan pengambilan keputusan, sehingga bisa memberikan pertimbangan yang baik bagi anak termasuk etika berkomunikasi di media sosial. Hal tersebut akan memberi pemahaman bagi anak mengenai perilaku-perilaku yang seharusnya dilakukan dalam menggunakan media sosial dan dapat menurunkan perilaku perundungan siber pada remaja.

Disarankan bagi pihak sekolah termasuk guru untuk dapat memberikan pandangan mengenai nilai-nilai moral yang seharusnya dilakukan oleh murid saat berkomunikasi melalui media sosial. Guru juga diharapkan merancang program penyuluhan bagi orang tua murid mengenai pengawasan terhadap perilaku anak. Hal tersebut diharapkan dapat mencegah perilaku perundungan siber pada remaja.

\section{Daftar Pustaka}

Asosiasi Penyelenggara Jasa Internet Indonesia [APJII]. (2016). Profil Pengguna Internet Indonesia. Diakses 17 Oktober 2017, dari Asosiasi Penyelenggara Jasa

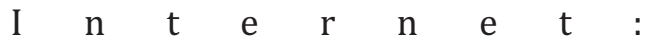
https://apjii.or.id/content/read/39/2 64/Survei-Internet-APJII-2016.

Goleman, D. (2007). Kecerdasan Emosional. Jakarta: PT Gramedia Pustaka Utama.

Hurlock, E. (2007). Psikologi Perkembangan Suat Pendekatan Sepanjang Rentang Kehidupan edisi kelima. Jakarta: PT Erlangga.
Maya, N. (2015). Fenomena cyberbullying di kalangan pelajar. Jurnal Ilmu Sosial dan Ilmu Politik, 4(3) 2442-6962.

Notoatmodjo, S. (2010). Metodologi Penelitian Kesehatan. Jakarta: Rineka Cipta.

Pratiwi, M. D. (2011). Faktor-faktor yang mempengaruhi cyberbullying pada remaja. Diakses pada tanggal 12 $0 \mathrm{k} \mathrm{t}$ o b e r 2017 , d a r i : https://www.scribd.com/doc/106227383/ Faktor-Faktor-Yang-MempengaruhiCyberbullying.

Priyatna, A. 2010. Lets End Bullying: Memahami, Mencegah, dan Mengatasi Bullying. Jakarta: PT. Elex Media Komputindo.

Rahayu, F. S. (2012). Cyberbullying sebagai dampak negatif penggunaan teknologi informasi. Journal of Information Sys te ms, $8(1), 22-31$. https://doi.org/10.21609/jsi.v8i1.321.

Surbakti, F. B. (2009). Kenalilah Anak Remaja Anda. Jakarta: PT. Elex Media Komputindo.

Valizadeh, S., Davaji, R., \& Nikamal, M. (2010). The Effectiveness of anger management skills training or reduction of agression in adolescents. Procedia Social and Behavioral Science: Iran. 5,1195-1199. https://doi.org/10.1016/j.sbspro.2010.07. $\underline{260}$.

Wilard, N. (2007). Cyberbullying and Cyberthreats. Washington: U.S Department of Education. 